\title{
PENGARUH WAKTU DAN SUHU PENGERINGAN TERHADAP KUALITAS PERMEN JELI
}

\section{Effect of Drying Time and Temperature on The Quality of Jelly Candy}

\author{
Ellya Sinurat ${ }^{1^{*}}$ dan Murniyati ${ }^{1}$ \\ ${ }^{1}$ Balai Besar Penelitian dan Pengembangan Pengolahan Produk dan Bioteknologi Kelautan dan Perikanan, \\ Jl. K.S. Tubun Petamburan VI, Jakarta Pusat, Indonesia \\ * Korespondensi Penulis: ellya_sinurat@yahoo.com
}

Diterima: 11 Oktober 2013; Disetujui: 25 November 2014

\begin{abstract}
ABSTRAK
Telah dilakukan formulasi permen jeli yang terdiri atas komponen utama yaitu bahan pembentuk gel yang merupakan campuran dari karaginan murni, konjak, dekstrose dan $\mathrm{KCl}$; ditambah dengan bahan-bahan lain dan air. Sebagai pembanding digunakan produk permen jeli transparan yang mengandung karaginan yang dibeli di pasaran. Penelitian ini dilakukan dalam dua tahap. Tahap pertama yaitu optimasi konsentrasi pembentuk gel, dengan variasi 2, 4, 6, dan 8\%. Pembuatan permen jeli dilakukan dengan mencampur bahan-bahan kering (karaginan, konjak, dekstrosa dan $\mathrm{KCl}$ ) dengan larutan gula kemudian ditambah air, dihomogenkan dan dimasak. Campuran yang sudah masak dituang ke dalam cetakan persegi, dan didiamkan pada suhu kamar. Setelah menjendal, dimasukkan ke dalam lemari pendingin pada suhu $10^{\circ} \mathrm{C}$ selama 24 jam, kemudian dipotong berbentuk kotak, lalu dikeringkan menggunakan oven pada suhu $40{ }^{\circ} \mathrm{C}$ selama 36 jam. Pengamatan dilakukan terhadap kadar air, aktivitas air dan kekuatan gel. Tahap kedua adalah pengeringan permen jeli yang dilakukan pada tiga suhu yang berbeda $\left(40,50\right.$, dan $\left.60{ }^{\circ} \mathrm{C}\right)$, dengan waktu pengeringan masing-masing $24,36,48$, 60, dan 72 jam. Pada tahap ini permen jeli dibuat menggunakan persentase bahan pembentuk gel konsentrasi terbaik yang diperoleh dari penelitian tahap pertama. Untuk mengetahui kualitas produk permen jeli, parameter mutu yang diamati meliputi kadar air, aktivitas air, sifat fisik (kekerasan, kelengketan, dan elastisitas), uji organoleptik (kenampakan, bau, rasa, tekstur, elastisitas, transparansi dan kesukaan). Hasil penelitian menunjukkan bahwa konsentrasi pembentuk gel terbaik adalah 6\%. Pengeringan optimum adalah pada suhu $60^{\circ} \mathrm{C}$ selama 36 jam dilihat dari parameter kadar air $(16,2 \%), a_{w}(0,71)$, sifat fisik (kekuatan gel $341,6 \mathrm{~g} / \mathrm{cm}^{2}$; kelengketan $6,2 \mathrm{~g} / \mathrm{cm}^{2}$ dan elastisitas $7,3 \mathrm{~mm}$ ) dan organoleptik (nilai skor 3) serta memenuhi persyaratan SNI 3547-2: 2008 (berdasarkan kadar air maksimum 20\%).
\end{abstract}

KATAKUNCI: Karaginan, pengeringan, permen jeli, konjak

\section{ABSTRACT}

Formulation of jelly candy consisted of a mixture of refined carrageenan, konjac, dextrose and $\mathrm{KCl}$ as the main component, added with other ingredient and water, has been carried out. As a reference a commercial transparent jelly candy containing carrageenan was used. This experiment was made in two stages. The first stage is optimization of gelling agent concentration which where 2, 4, 6, and 8\%. Jelly candy was made by mixing dry ingredients (carrageenan, konjac, dextrose, and $\mathrm{KCl}$ ) with sugar solution and water, followed by homogenization and cooking. After cooking candy solution was poured into a square mold, and allowed to stand at room temperature. After gelling, candies were put in the refrigerator at a temperature of $10^{\circ} \mathrm{C}$ for 24 hours, then cut in rectangular shape, and then dried using oven at a temperature of $40^{\circ} \mathrm{C}$ for 36 hours and assessed for its water content, water activity, and gel strength. The second stage was drying of jelly candy at three different temperatures $\left(40,50\right.$ and $\left.60^{\circ} \mathrm{C}\right)$, and different drying time which where $24,36,48$, 60 and 72 hours. To determine the quality of jelly candy, the parameters observed were moisture content, water activity, physical properties (hardness, stickyness and elasticity) and organoleptic characteristic (appearance, odor, flavor, texture, elasticity, transparency and hedonic series). The results showed that the best concentration of gelling agent was 6\%. Based on the physical and organoleptic properties, and the conformity to moisture content required by national standar (SNI 3547-2: 2008), the optimum drying method was at $60{ }^{\circ} \mathrm{C}$ for 36 hours which gave product with water content of $16.2 \%, a_{w}$ of 0.71 , gel strength of $341.6 \mathrm{~g} / \mathrm{cm}^{2}$; stickiness of $6.2 \mathrm{~g} / \mathrm{cm}^{2}$ and the elasticity of $7.3 \mathrm{~mm}$ while the organoleptic score was 3.00 .

KEYWORDS: carrageenan, drying, jelly candy, konjac 


\section{PENDAHULUAN}

Karaginan merupakan fikokoloid yang diperoleh dari hasil ekstrak rumput laut merah (rodofita). Karaginan berfungsi sebagai stabilisator, bahan pengental, pembentuk gel atau pengemulsi dalam bidang industri (Winarno, 1996). Berdasarkan kandungan sulfatnya, Doty (1987) membedakan karaginan menjadi dua bagian yaitu $k$-karaginan yang mengandung sulfat kurang dari $28 \%$ dan $i$-karaginan jika sulfat lebih dari 30\%. Banyak faktor yang membedakan karaginan, namun faktor yang paling penting adalah kelarutannya dalam air, viskositas dan stabilitasnya (Suryaningrum, 1988). K-karaginan dapat digunakan untuk bahan penstabil karena mengandung gugus sulfat yang bermuatan negatif di sepanjang rantai polimernya dan bersifat hidrofilik yang dapat mengikat air (Suryaningrum et al., 2002)

Selain fikokoloid, banyak bahan aditif lain yang fungsinya mirip dengan fikokoloid yang digunakan dalam industri makanan diantaranya adalah guar gum, Locust Bean Gum (LBG), gum arabik dan konjak (Miller \& Whistler, 1973). Konjak atau yang disebut konjak manan atau konyaku adalah polisakarida hidrokoloid berasal dari tanaman Amorphophallus. Komponen utamanya berupa senyawa glukomanan terdiri dari manosa dan glukosa, dihubungkan dengan ikatan $\beta-1,4$. Glukomanan memiliki berat molekul antara 200 sampai $2.000 \mathrm{kD}$, kandungan karbohidratnya tidak lebih dari $75 \%$. Warna tepungnya putih sampai krem atau kecoklatan. Konjak larut dalam air panas atau air dingin, kekentalannya tinggi dengan $\mathrm{pH}$ antara 4,0 sampai 7,0 , berfungsi sebagai bahan pembentuk gel, pengental, emulsifier dan penstabil (Anon., 2002).

Aplikasi karaginan dan konjak dapat digunakan dalam industri makanan sebagai suspensi dalam yoghurt, penstabil dalam es krim dan sebagai pembentuk gel dalam jeli dan permen atau dikenal dengan permen jeli. Konjak merupakan senyawa glukomanan yang bersifat kenyal dan mempunyai sinergisme dengan karaginan dalam hal sifat kekuatan gel dan kekenyalan (Sinurat et al., 2006). Bahan lain yang digunakan sebagai bahan pembentuk gel pada permen jeli antara lain : gelatin, agar, dan alginat (Mulyasari et al., 2003; Maryani et al., 2010; Anita, 2011).

Menurut DSN No. 013547 (1994b) dalam Sholeh (2004) kembang gula atau permen adalah jenis makanan selingan dalam bentuk padat, dibentuk dari gula atau pemanis lain dengan atau tanpa bahan makanan lain dan bahan makanan tambahan yang diijinkan. Kembang gula diklasifikasikan dalam empat jenis yaitu: kembang gula keras, kembang gula lunak, kembang gula karet dan kembang nirgula. Permen jeli termasuk kembang gula lunak yang mempunyai tekstur kenyal dan elastis. Permen jeli merupakan permen yang terbuat dari komponen air atau sari buah, flavour, gula dan bahan pembentuk gel (Sholeh, 2004; Helmi et al., 2006). Permen jeli juga dapat dibuat dari ekstrak rumput laut yang berupa karaginan (Salamah, 2006) dan produk permen jeli dibuat beraneka ragam rasa dengan menambahkan berbagai macam rasa seperti buah tomat dan susu, jambu biji dan timun suri yang semuanya dilakukan untuk menambah kandungan gizi pada permen jeli (Septiani, 2009; Indriyani et al., 2010).

Permen jeli termasuk dalam produk pangan semi basah, karena bahan utamanya adalah air, bahan perasa dan bahan lain yang dapat membentuk gel. Oleh karena itu produk ini mudah mengalami kerusakan, sehingga untuk memperpanjang daya simpan perlu dilakukan pengeringan yang tepat (Khoiriah, 2012).

Pengeringan merupakan proses penurunan kadar air bahan sampai mencapai kadar air tertentu sehingga dapat memperlambat laju kerusakan produk akibat aktivitas biologi dan kimia. Menurut Hasibun (2005) pengeringan merupakan penghidratan, yang berarti menghilangkan air dari suatu bahan. Proses pengeringan produk pangan bergantung pada struktur bahan beserta parameter pengeringan: kadar air, dimensi produk, suhu medium pemanas, berbagai laju perpindahan pada permukaan dan kesetimbangan kadar air. Laju pengeringan suatu bahan yang dikeringkan antara lain ditentukan oleh sifat bahan tersebut seperti densitas yang tinggi, kadar air awal, serta hubungannya dengan kesetimbangan kadar air pada kondisi pengeringan (Anon., 2012). Menurut Setyoko et al. (2008), proses pengeringan juga dipengaruhi energi pengeringan dan kapasitas pengeringan. Pengeringan yang terlampau cepat dapat merusak bahan karena permukaan bahan terlalu cepat kering sehingga kurang bisa diimbangi dengan kecepatan gerakan air di bagian dalam bahan menuju permukaan. Lebih lanjut, pengeringan cepat menyebabkan pengerasan pada permukaan bahan sehingga air dalam bahan tidak dapat lagi menguap karena terhambat. Di samping itu, kondisi pengeringan dengan suhu yang terlalu tinggi dapat merusak bahan. Pengaturan suhu dan lamanya waktu pengeringan dilakukan dengan memperhatikan kontak antara alat pengering dengan alat pemanas (baik berupa udara panas yang dialirkan maupun alat pemanas lainnya). Namun demi pertimbangan-pertimbangan standar gizi maka pemanasan dianjurkan tidak lebih dari $85^{\circ} \mathrm{C}$.

Selama ini pengeringan permen jeli dilakukan dengan bermacam-macam cara, antara lain menggunakan suhu $50{ }^{\circ} \mathrm{C}$ selama 6 jam (Rahmi, 1996; Mulyasari et al., 2003) dan ada yang 
menggunakan oven pada suhu $60{ }^{\circ} \mathrm{C}$ selama 36 jam (Murdinah, 2010).

Tujuan penelitian ini adalah untuk mengetahui konsentrasi terbaik bahan pembentuk gel serta suhu dan lama pengeringan terhadap mutu produk permen jeli.

\section{BAHAN DAN METODE}

\section{Bahan}

Bahan utama yang digunakan dalam penelitian ini adalah karaginan murni hasil ekstraksi dari rumput laut Eucheuma cottonii (diambil dari Pulo Panjang, Kecamatan Merak, Kabupaten Serang-Banten) menggunakan metode yang dimodifikasi Utomo (2004). Mutu karaginan yang diperoleh memiliki kekuatan gel $1050 \mathrm{~g} / \mathrm{cm}^{2}$, dan viskositas $125 \mathrm{cPs}$ pada konsentrasi 1,5\%. Bahan lain yang digunakan meliputi: konjak CKAA 2030 dari Trading Indokemika (Jakarta), flavour dan essens dari PT. Diamond (Jakarta), potasium sitrat, $\mathrm{KCl}$, tepung tapioka, gula halus, dekstrosa, dan fruktosa dari toko bahan kimia di Jakarta.

\section{Alat}

Peralatan yang digunakan Texture analyzer (TAXTPlus), a sprint merk Novasina model TH 500.

\section{Metode}

Penelitian ini dilakukan dalam dua tahap yaitu : tahap pertama optimasi penggunaan bahan pembentuk gel permen jeli dan tahap kedua optimasi suhu dan lama pengeringan permen jeli yang dibuat dengan konsentrasi bahan pembentuk gel yang diperoleh dari penelitian tahap pertama.

\section{Optimasi konsentrasi bahan pembentuk gel}

Bahan pembentuk gel adalah formula utama bahan permen jeli yang merupakan campuran antara karaginan murni (40\%), konjak (40\%), dekstrose (15\%) dan $\mathrm{KCl}(5 \%)$. Bahan ini digunakan dalam jumlah yang divariasi terhadap bahan lain yang digunakan dalam pembentukan permen jeli.

Pada penelitian tahap pertama, ditentukan optimasi konsentrasi bahan pembentuk gel. Untuk setiap $100 \mathrm{~g}$ permen jeli digunakan HFS (high fructosa syrup) $20 \%$, gula $35 \%$, potasium sitrat $0,2 \%$, essens dan flavour $0,3 \%$, natrium benzoat $0,03 \%$ dan bahan pembentuk gel yang jumlahnya divariasi $(2,4,6$, dan 8\%). Air ditambahkan untuk mencapai jumlah $100 \mathrm{~g}$. Pembuatan permen jeli diawali dengan melarutkan gula dan HFS dalam air panas, kemudian bahan pembentuk gel dimasukkan dan dimasak pada suhu $90{ }^{\circ} \mathrm{C}$ selama 5 menit, adonan kemudian dituang ke dalam cetakan persegi, dan didiamkan sampai mencapai suhu kamar. Setelah menjendal, produk dimasukkan ke dalam lemari pendingin pada suhu 1$4{ }^{\circ} \mathrm{C}$ selama 24 jam. Setelah itu, produk dikeluarkan dari cetakan kemudian dipotong persegi dengan ukuran 1 x 1,5 ×2,5 cm, lalu dikeringkan menggunakan oven pada suhu $40^{\circ} \mathrm{C}$ dengan waktu pengeringan 36 jam.

Untuk mengetahui mutu permen jeli dilakukan analisis kadar air, aktivitas air $\left(\mathrm{a}_{\mathrm{w}}\right)$ dan kekuatan gel dibandingkan dengan permen jeli komersial. Kadar air diukur dengan metode AOAC (2000). Pengukuran $\mathrm{a}_{\mathrm{w}}$ dilakukan sampai pembacaan nilai $\mathrm{a}_{\mathrm{w}}$ konstan, dengan larutan standar $25 \% \mathrm{MgCl}_{2} 6 \mathrm{H}_{2} \mathrm{O}$ (Sudarmadji et al. 1989). Pengukuran kekuatan gel dilakukan terhadap sampel yang dipotong dengan ukuran $1 \mathrm{~cm}$ $x 1,5 \mathrm{~cm} \times 2,5 \mathrm{~cm}$ menggunakan probe nomor $\mathrm{p} / 2$ (diameter $2 \mathrm{~mm}$ ) dengan kedalaman penekanan terhadap sampel (distance) $8 \mathrm{~mm}$ (Tuazon, 1996). Preparasi sampel untuk penentuan kekuatan gel dilakukan menurut AOAC (2000). Bahan pembentuk gel dilarutkan dalam air (konsentrasi 1,5\%), dipanaskan sampai $75^{\circ} \mathrm{C}$ dan dipertahankan selama 10 menit pada suhu tersebut, lalu disimpan pada suhu $10^{\circ} \mathrm{C}$ selama 1 malam.

\section{Optimasi suhu dan lama pengeringan}

Pada penelitian tahap kedua permen jeli dibuat menggunakan konsentrasi bahan pembentuk gel terbaik dari penelitian tahap pertama; dengan prosedur yang sama dengan tahap pertama; sedangkan pengeringan dilakukan dengan variasi suhu 40, 50, dan $60^{\circ} \mathrm{C}$, dan waktu pengeringan masing-masing 24 , 36, 48, 60, dan 72 jam. Penelitian dilakukan menggunakan ulangan sebanyak 3 kali. Parameter kualitas fisik produk yang diamati adalah kadar air, aktivitas air, dan profil sifat fisik yang meliputi kekuatan gel, kelengketan dan elastisitas serta pengamatan secara organoleptik. Uji organoleptik dilakukan terhadap produk dengan parameter rupa, bau, rasa, tekstur, elastisitas dan penerimaan hedonik menggunakan skala 1-5 yaitu: (1). sangat tidak suka, (2). tidak suka, (3). agak suka, (4). suka, (5). sangat suka dengan panelis sebanyak 15 orang. Parameter dan skor penilaian yang diajukan kepada panelis dapat dilihat pada Lampiran 1.

\section{Analisis Data}

Analisis data dilakukan dengan analisis sidik ragam (anova) dan apabila berbeda nyata dilanjutkan dengan uji berpasangan Tukey (Gomez \& Gomez, 1995). Sedangkan untuk data organoleptik dilakukan dengan 
uji Kruskal-Walis. Analisis statistik dilakukan dengan bantuan program statistik minitab versi 14 .

\section{HASIL DAN PEMBAHASAN}

\section{Optimasi Konsentrasi Bahan Pembentuk Gel}

Hasil pengujian mutu permen jeli pada tahap optimasi (variasi konsentrasi bahan pembentuk gel) pada suhu $40^{\circ} \mathrm{C}$ dengan lama pengeringan 36 jam dapat dilihat pada Tabel 1. Mutu permen jeli yang paling mendekati produk komersial $\left(504 \mathrm{~g} / \mathrm{cm}^{2}\right)$ dilihat dari kekuatan gelnya adalah bahan pembentuk gel pada konsentrasi $6 \%\left(583,5 \mathrm{~g} / \mathrm{cm}^{2}\right)$. Kekuatan gel permen jeli dengan konsentrasi bahan pembentuk gel $8 \%$ jauh lebih tinggi $\left(745 \mathrm{~g} / \mathrm{cm}^{2}\right)$ dan sangat kental sehingga sebagian masih ada yang tidak larut, karena sudah jenuh sehingga dianggap tidak membentuk gel pada konsentrasi tersebut. Formula dengan konsentrasi bahan pembentuk gel 2\% tidak membentuk gel, sehingga kekuatan gelnya tidak terukur, dan kadar air maupun $a_{w}$ juga tidak dapat ditentukan.

Bila dilihat dari kadar air dan $\mathrm{a}_{\mathrm{w}}$, kadar air permen jeli hasil penelitian masih jauh lebih tinggi dibandingkan permen jeli komersial. Untuk mendapatkan kadar air yang mendekati permen jeli komersial dan memenuhi persyaratan perlu dilakukan optimasi lama dan suhu pengeringan.

\section{Optimasi Suhu dan Lama Pengeringan}

\section{Sifat fisik}

\section{Kadar air}

Kadar air permen jeli tertinggi adalah 28,3\% yang diperoleh dari pengeringan pada suhu $40^{\circ} \mathrm{C}$ selama 24 jam, sedangkan kadar air terendah adalah 18,0\% dari permen jeli yang dikeringkan pada suhu $60^{\circ} \mathrm{C}$ selama 72 jam. Bila dibandingkan dengan permen jeli komersial, pengeringan pada suhu $60^{\circ} \mathrm{C}$ dengan lama pengeringan 36-72 jam menghasilkan produk yang lebih mendekati permen jeli pembanding dan sesuai dengan standar SNI yaitu di bawah $20 \%$.

Berdasarkan hasil uji statistik diketahui bahwa variasi suhu dan lama pengeringan memberikan perbedaan nyata di antara perlakuan. Pengeringan permen jeli pada suhu $40{ }^{\circ} \mathrm{C}$, antara waktu pengeringan 24 jam dan 72 jam berbeda nyata, sedangkan waktu pengeringan 60 dengan 72 jam tidak berbeda nyata. Adapun pengeringan permen jeli pada suhu $50^{\circ} \mathrm{C}$, antara waktu pengeringan 24 jam dan 72 jam berbeda nyata, sedangkan antara waktu pengeringan 48,60, dan 72 jam pada suhu $50^{\circ} \mathrm{C}$ tidak berbeda nyata, sedangkan pengeringan pada suhu $60^{\circ} \mathrm{C}$ antara waktu pengeringan 24 jam dengan 48 jam tidak berbeda nyata. Hal yang sama juga terlihat bahwa pengeringan suhu $50{ }^{\circ} \mathrm{C}$ selama 36 dan 48 jam dengan suhu pengeringan $60^{\circ} \mathrm{C}$ selama 24 dan 48 jam tidak berbeda nyata. Bila dibandingkan dengan kadar air permen jeli komersial maka pengeringan yang optimum adalah pada suhu $50^{\circ} \mathrm{C}$ selama 60 jam yang memiliki kadar air 14,3\% atau pengeringan optimum dengan suhu $60^{\circ} \mathrm{C}$ selama 60 jam yang memiliki kadar air 12,2\%. Kadar air permen jeli yang dikeringkan pada suhu $50{ }^{\circ} \mathrm{C}$ atau $60{ }^{\circ} \mathrm{C}$ selama 60 jam masih memenuhi SNI 3547.2-2008 (BSN, 2008) untuk kembang gula lunak yaitu maksimum 20\%. Penurunan kadar air mulai terjadi secara signifikan setelah dilakukan pengeringan selama 36 jam untuk ketiga variasi suhu $(40,50$, dan 60) jam.

Pada pengeringan permen jeli selama 24 jam sampai 36 jam terjadi penurunan kadar air yang cukup signifikan untuk masing-masing suhu pengeringan. Hal ini disebabkan oleh penguapan air permukaan atau air bebas yang terdapat pada permen jeli.

Tabel 1. Mutu permen jeli dengan variasi bahan pembentuk gel yang berbeda

Table 1. Quality of jelly candy of various gelling agent concentration

\begin{tabular}{|c|c|c|c|c|c|c|}
\hline \multirow{2}{*}{ ParameterIParameter } & \multicolumn{6}{|c|}{$\begin{array}{c}\text { Persentase Bahan Pembentuk Gel dalam Formula Permen Jelil } \\
\text { Percentage of Gelling Agent in Jelly Candy Formula }\end{array}$} \\
\hline & 2 & 4 & 6 & 8 & PK & $\begin{array}{l}\text { Persyaratan/Requirement } \\
\text { (BSN, 2008) }\end{array}$ \\
\hline Kadar air/Moisture content (\%) & $\mathrm{Tt}$ & 24.80 & 23.40 & 21.70 & 9.00 & Maks/Max 20 \\
\hline$a_{w}$ & $\mathrm{Tt}$ & 0.78 & 0.76 & 0.75 & 0.70 & - \\
\hline Kekuatan gel/Gel strength $\left(\mathrm{g} / \mathrm{cm}^{2}\right)$ & $\mathrm{Tt}$ & 345.00 & 583.50 & 745.00 & 504.00 & - \\
\hline
\end{tabular}

Keterangan/Note: Tt : tidak terukur karena terlalu basah/Tt not detected;

PK : produk komersial/PK : commercial product 


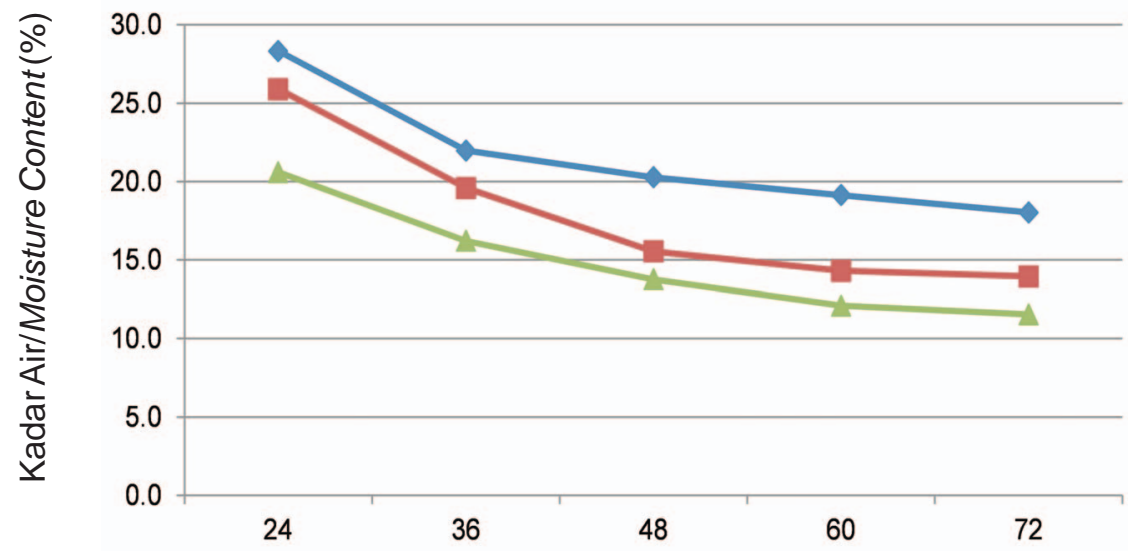

Waktu Pengeringan (Jam)/Drying Time (hours)

$\sim$ Suhu/Temperature $40^{\circ} \mathrm{C}=$ Suhu/Temperature $50^{\circ} \mathrm{C}=$ Suhu/Temperature $60^{\circ} \mathrm{C}$

Gambar 1. Kadar air permen jeli setelah dikeringkan pada suhu dan waktu yang berbeda.

Figure 1. Moisture content analysis of jelly candy after drying at different time and temperature.

Pengeringan pada suhu $60^{\circ} \mathrm{C}$ paling cepat mengalami penurunan kadar air karena energinya paling tinggi. Untuk menguapkan air bebas ini dibutuhkan energi yang kecil sehingga mudah menguap. Pada pengeringan lebih dari 36 jam laju pengeringan mulai menurun, hal ini disebabkan perpindahan air terjadi di dalam bahan padat produk, tidak dipengaruhi oleh kondisi di luar bahan padat tersebut. Bermacammacam mekanisme perpindahan air dalam produk bisa terjadi karena kombinasi berbagai faktor seperti difusi cairan, perpindahan cairan karena tenaga kapiler dan difusi uap air (Anon., 2012).

\section{Aktivitas air $\left(a_{w}\right)$}

Berdasarkan hasil analisis aktivitas air $\left(a_{w}\right)$ pada Gambar 2, pengeringan pada suhu $40^{\circ} \mathrm{C}$ selama 24 jam memberikan nilai $a_{w}$ tertinggi sebesar 0,80 , sedangkan terendah sebesar 0,71 dihasilkan dari perlakuan pengeringan selama 72 jam pada suhu 60 ${ }^{\circ} \mathrm{C}$. Pengeringan pada suhu 50 dan $60^{\circ} \mathrm{C}$ selama 36 jam sampai 72 jam, diperoleh nilai $a_{w}$ yang hampir berdekatan $(0,74-0,71)$.

Pengeringan pada suhu $50^{\circ} \mathrm{C}$ selama 36 dan 48 jam memberikan $\mathrm{a}_{\mathrm{w}}$ yang tidak berbeda nyata dengan

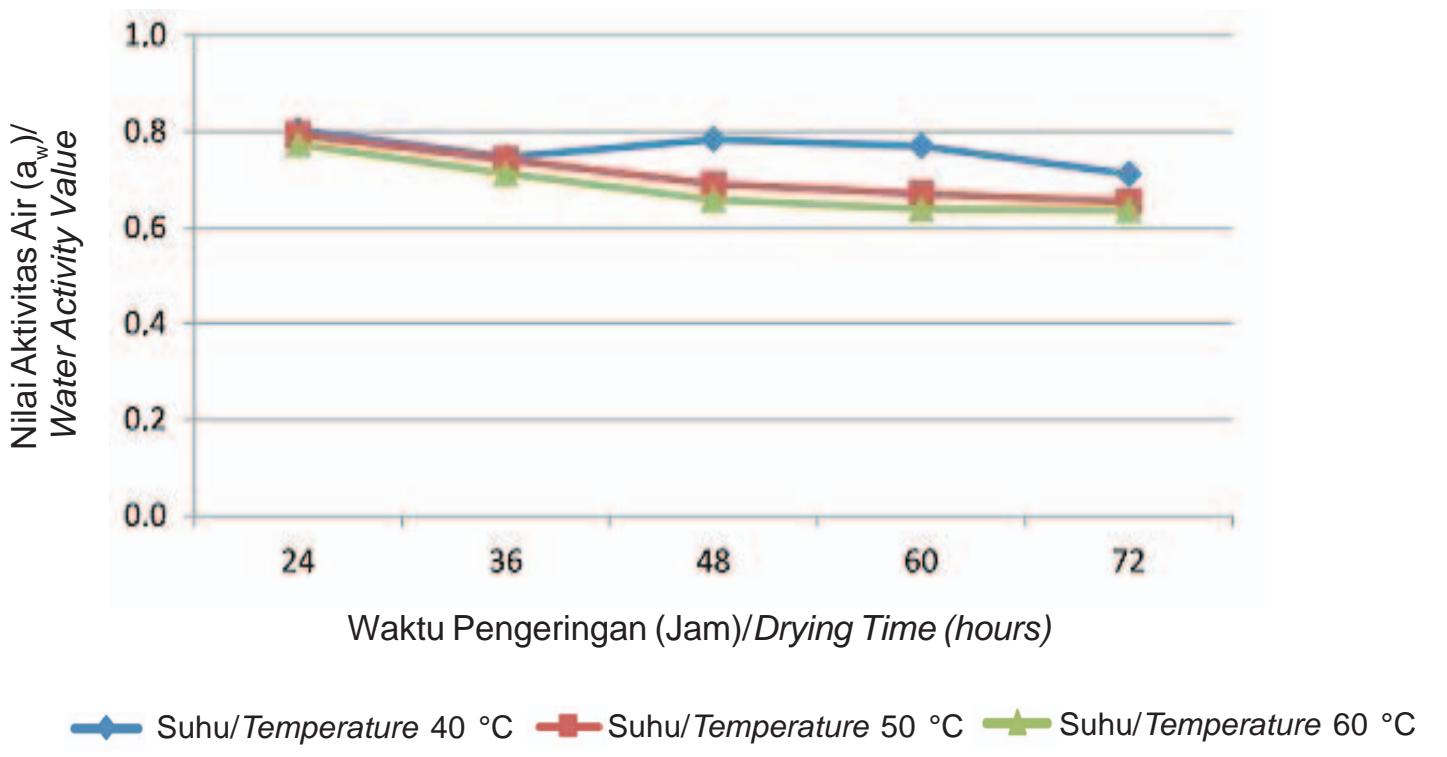

Gambar 2. Aktivitas air $\left(\mathrm{a}_{\mathrm{w}}\right)$ permen jeli pada berbagai suhu dan waktu pengeringan.

Figure 2. Water activity of jelly candy at different time and temperature of drying. 
pengeringan pada $60^{\circ} \mathrm{C}$ selama 24 jam dan 36 jam. Secara umum variasi suhu dan lama pengeringan menunjukkan pengaruh nyata terhadap aktivitas air. Aktivitas air $\left(a_{w}\right)$ merupakan parameter yang menunjukkan besarnya air bebas dalam suatu produk, yang memungkinkan bagi mikroorganisme untuk hidup. Semakin kecil nilai $a_{w}$ suatu produk maka daya simpan produk tersebut semakin lama karena mikroorganisme dan kapang hanya bisa hidup pada kondisi $\mathrm{a}_{\mathrm{w}}$ tertentu (Winarno et al., 1980). Menurut Winarno (1983) aktivitas air minimum untuk pertumbuhan bakteri dan kapang adalah 0,7.

\section{Profil Sifat Fisik (Kekuatan gel, Kelengketan, dan Elastisitas) dari Permen Jeli}

Hasil analisis menunjukkan bahwa kekuatan gel berbanding lurus dengan lama pengeringan, yaitu semakin lama pengeringan, nilai kekuatan gelnya semakin tinggi. Nilai kekuatan gel tertinggi diperoleh pada pengeringan suhu $60^{\circ} \mathrm{C}$ selama 72 jam, sedangkan nilai terendah diperoleh pada pengeringan suhu $40^{\circ} \mathrm{C}$ selama 24 jam. Nilai kelengketan dan elastisitas permen jeli dari semua suhu dan waktu pengeringan hampir sama. Kekuatan gel permen jeli hasil penelitian yang paling mendekati permen jeli komersial $\left(502 \mathrm{~g} / \mathrm{cm}^{2}\right)$ diperoleh dari pengeringan pada suhu $50{ }^{\circ} \mathrm{C}$ selama 60 jam.

Nilai kelengketan merupakan besarnya gaya tarik sampel melawan arah gaya probe pada saat penarikan kembali gaya oleh texture-analyzer sehingga diberi tanda negatif. Nilai elastisitas dinyatakan dengan besarnya jarak antara garis y dengan absis pada saat terjadinya deformasi sampel tersebut (Canovas \& Munizaga, 2000).

Berdasarkan hasil analisis sifat fisik permen jeli pada parameter kekuatan gel, lama pengeringan dan suhu berbanding lurus dengan kekuatan gel. Hal ini berhubungan dengan menurunnya kadar air dalam permen jeli, yaitu bila kadar air semakin rendah maka kekuatan gel semakin tinggi.

Pada parameter kelengketan terjadi kenaikan kelengketan mulai pengeringan sampai pada jam ke-
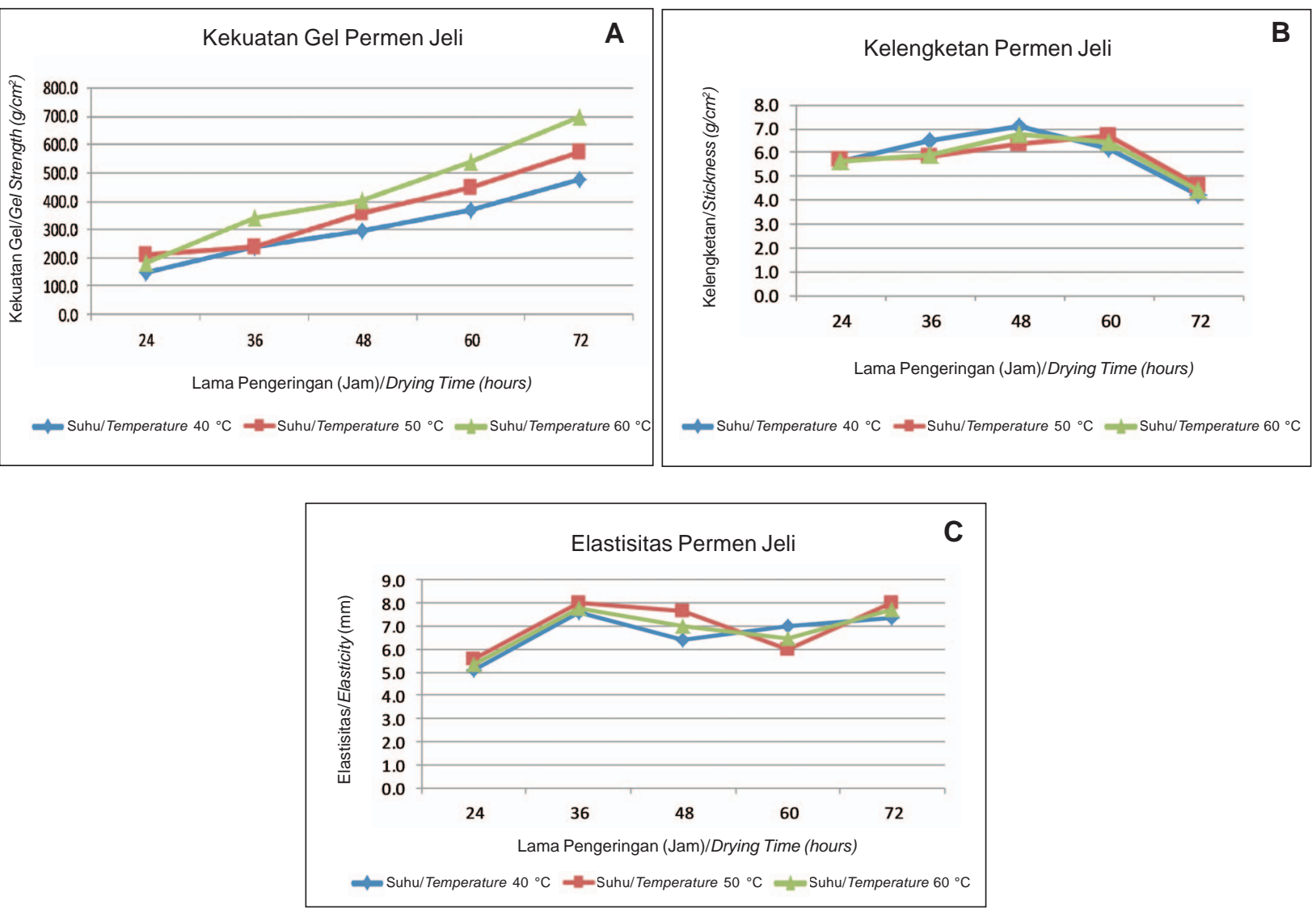

Gambar 3. Profil sifat fisik permen jeli: kekuatan gel (A), kelengketan (B), elastisitas (C) permen jeli dengan berbagai suhu dan waktu pengeringan.

Figure 3. Phisical profile of jelly candy : gel strength (A), stickyness (B), elasticity (C) of jelly candy of various time and temperature of drying. 
48, kemudian mulai menurun setelah 48 jam. Kemungkinan kenaikan kelengketan permen jeli disebabkan penguapan air permukaan sehingga terjadi kerapatan antar matriks pada bahan tersebut yang menyebabkan meningkatnya kelengketan. Sedangkan setelah pengeringan 48 jam kemungkinan terjadi perpindahan air sebagian dari matriks permen jeli sehingga kerapatannya berkurang dan menyebabkan kelengketan berkurang (Anon., 2014).

\section{Hasil Organoleptik Permen Jeli}

Hasil organoleptik secara keseluruhan dapat dilihat pada Tabel 2. Perlakuan variasi suhu dan lama pengeringan tidak berpengaruh terhadap parameter aroma dan rasa, sedangkan parameter yang dipengaruhi secara nyata adalah tekstur (kekerasan), elastisitas dan transparansi. Berdasarkan nilai hedonik pengeringan pada suhu $50^{\circ} \mathrm{C}$ selama 24 dan 36 jam tidak berbeda nyata dengan skor antara 3,293,43 atau secara hedonik dinyatakan agak suka sampai suka. Transparansi menurut penilaian panelis nilainya bervariasi. Hal ini kemungkinan karena panelis ini masih semi terlatih.

Berdasarkan uji Kruskal-Walis terlihat adanya perbedaan nyata antara pengeringan pada suhu 40 ${ }^{\circ} \mathrm{C}$ selama 36 dan 48 jam dan pengeringan pada suhu $50{ }^{\circ} \mathrm{C}$ selama 24 dan 36 jam dan pengeringan pada suhu $60^{\circ} \mathrm{C}$ selama 24 jam, tetapi antara pengeringan pada suhu $50{ }^{\circ} \mathrm{C}$ selama 24 dan 36 jam dan pengeringan pada suhu $60^{\circ} \mathrm{C}$ selama 24 jam tidak berbeda dalam hal transparansi.

Hasil uji sensori secara hedonik menunjukkan nilai permen jeli berada di antara skor 2,25 hingga 3,75. Sedangkan untuk produk permen jeli komersial penilaian panelis memberikan skor 4,14. Skor border line adalah 3 yang berarti agak suka. Berdasarkan hasil organoleptik secara hedonik tersebut nilai skor tertinggi $(3,75$ dan 3,71$)$ yang mendekati permen jeli komersial $(4,14)$ dicapai oleh pengeringan pada $60^{\circ} \mathrm{C}$ selama 24 jam dan pada suhu $40^{\circ} \mathrm{C}$ selama 36 jam dan 48 jam, namun demikian kadar air dari kedua perlakuan tersebut masih berada di atas $20 \%$ sehingga

Tabel 2. Karakteristik organoleptik permen jeli

Table 2. Organoleptic characteristic of jelly candy

\begin{tabular}{ccccccc}
\hline \multirow{2}{*}{$\begin{array}{c}\text { Kode Sampell } \\
\text { Sample Code }\end{array}$} & \multicolumn{5}{c}{ Karakteristik/Characteristics (skor/score) } \\
\cline { 2 - 7 } & $\begin{array}{c}\text { Teksturl } \\
\text { Texture }\end{array}$ & $\begin{array}{c}\text { Elastisitas/ } \\
\text { Elasticity }\end{array}$ & Transparansil & Aromal & Rasal & Hedonikl \\
& 3.86 & 3.71 & 3.71 & 4.29 & 4.29 & 3.00 \\
\hline $\mathrm{T}_{40} \mathrm{t}_{24}$ & 4.29 & 4.00 & 4.14 & 4.43 & 4.43 & 3.71 \\
$\mathrm{~T}_{40} \mathrm{t}_{36}$ & 4.71 & 4.14 & 3.86 & 4.29 & 4.29 & 3.71 \\
$\mathrm{~T}_{40} \mathrm{t}_{48}$ & 4.57 & 3.71 & 3.57 & 4.00 & 3.86 & 3.71 \\
$\mathrm{~T}_{40} \mathrm{t}_{60}$ & 2.29 & 2.57 & 2.57 & 4.14 & 3.14 & 2.43 \\
$\mathrm{~T}_{40} \mathrm{t}_{72}$ & 4.14 & 4.00 & 3.71 & 4.43 & 4.00 & 3.29 \\
$\mathrm{~T}_{50} \mathrm{t}_{24}$ & 4.29 & 3.71 & 3.86 & 4.29 & 4.43 & 3.43 \\
$\mathrm{~T}_{50} \mathrm{t}_{36}$ & 2.86 & 3.00 & 2.86 & 4.00 & 3.71 & 2.71 \\
$\mathrm{~T}_{50} \mathrm{t}_{48}$ & 3.00 & 2.63 & 3.13 & 4.00 & 4.13 & 3.00 \\
$\mathrm{~T}_{50} \mathrm{t}_{60}$ & 2.63 & 2.50 & 3.25 & 3.75 & 3.88 & 2.75 \\
$\mathrm{~T}_{50} \mathrm{t}_{72}$ & 4.25 & 3.88 & 3.38 & 4.25 & 4.38 & 3.75 \\
$\mathrm{~T}_{60} \mathrm{t}_{24}$ & 3.75 & 3.63 & 3.38 & 4.13 & 3.88 & 3.38 \\
$\mathrm{~T}_{60} \mathrm{t}_{36}$ & 2.75 & 2.75 & 3.25 & 3.75 & 3.75 & 2.38 \\
$\mathrm{~T}_{60} \mathrm{t}_{48}$ & 2.13 & 2.50 & 3.25 & 4.00 & 3.38 & 2.38 \\
$\mathrm{~T}_{60} \mathrm{t}_{60}$ & 2.00 & 2.13 & 3.00 & 3.88 & 3.50 & 2.25 \\
$\mathrm{~T}_{60} \mathrm{t}_{72}$ & 4.14 & 3.71 & 3.71 & 4.71 & 4.86 & 4.14 \\
Produk Komersial/ & & & & & & \\
Commercial Product & & & & & & \\
\hline
\end{tabular}

Keterangan/Note: $\mathrm{T}=$ Suhu/Temperature $\left({ }^{\circ} \mathrm{C}\right)$ $\mathrm{t}=$ Lama pengeringan (jam)/Drying time (hours) 
tidak memenuhi standar SNI 3547.2-2008 (BSN, 2008). Oleh karena itu dipilih perlakuan yang memberikan skor tertinggi berikutnya, yaitu 3,38 yang diperoleh dari pengeringan pada suhu $60^{\circ} \mathrm{C}$ selama 36 jam.

\section{KESIMPULAN}

Dari hasil penelitian yang dilakukan diperoleh kesimpulan bahwa konsentrasi optimum pembentuk gel adalah $6 \%$ dan teknik pengeringan permen jeli menggunakan oven yang optimum adalah pada suhu $60{ }^{\circ} \mathrm{C}$ selama 36 jam. Perlakuan tersebut menghasilkan permen jeli dengan kadar air 16,2\% (memenuhi persyaratan SNI 3547.2-2008), $a_{w} 0,71$, kekuatan gel $341,6 \mathrm{~g} / \mathrm{cm}^{2}$; kelengketan $6,2 \mathrm{~g} / \mathrm{cm}^{2}$ dan elastisitas 7,3 mm dan nilai skor organoleptik 3,38.

\section{DAFTAR PUSTAKA}

Anita, Y. (2011). Kadar Zat Besi, Serat, Gula total dan Daya Terima Permen Jeli dengan Penambahan Rumput Laut Gracilaria sp dan Sargassum sp. Artikel Penelitian. Program Studi IImu Gizi Fakultas Kedokteran, Undip.

Anonymous. (2002). Konjac, FAO Prepared at the $46^{\text {th }}$ JECFTA. http ://apps3.fao.org /jecfta/additive_specs / docs/4/additive 0623.htm. Diakses pada tanggal 22 Maret 2005.

Anonymous. (2012). web.ipb.ac.id/ tepfteta/elearning/ media/.../bab8.php. Diakses pada tanggal 21 November 2013

Anonymous. (2014). http://fpik.bunghatta.ac.id/files/ d o w n l o a d s/E - bo ok / D a s a r Dasar\%20Teknologi\%20Hasil\%20Perikanan/ bab_5.pdf. Diakses pada tanggal 10 Desember 2014.

[AOAC] Association of Analytical Chemist. (2000). Official Methods of Analysis. Association of Analytical Chemist. Washington DC. 1018 p.

[BSN] Badan Standarisasi Nasional. (2008). Kembang gula-Bagian 2: Lunak. SNI 3547.2-2008. Badan Standarisasi Nasional.

Canovas, G.V. \& Munizaga T. (2000). Rheological Characterization of Food Gels. Proceedings of The XIII th. International Congress on Rheology, Cambridge UK.

Doty, M.S. (1987). The Production and Uses of Eucheuma: Studies of Seven Commercial Seaweed Resources. Ed. By: M.S. Doty, J.F. Caddy and B. Santelices. FAO Fish. Tech. Paper. No. 281, Rome.

Gomez K.A. \& Gomez, A.A. (1995). Prosedur Statistik untuk Analisis Pertanian. Edisi Kedua Terjemahan Oleh: Sjamsuddin, E. \& Baharsjah, J.S. UI Press Jakarta. $697 \mathrm{p}$.

Hasibun, R. (2005). Proses Pengeringan. Program Studi Teknik Kimia Fakultas Teknik Sumatra Utara

Helmi, N., Ivanti, L., Hanifah, H., Khoirudin, M.N., \& Febrial, E. (2006). Pengembangan Ubi Jalar Sebagai Produk
Konfeksioneri Permen Jeli Prebiotik. Kumpulan Naskah Program Kreatifitas Mahasiswa Penulisan Ilmia (PKMI), Malang.

Indriyani M.S., Lidiasari, E., \& Indawan, H. (2010). Karakteristik permen jeli timun suri (Cucumis melo L.) sengan penambahan sorbitol dan ekstrak kunyit (Curcuma domestika Val). Jurnal Gizi dan Pangan. 5(2): 78-86.

Khoiriah L.N. (2012). Studi Eksperimen Pembuatan Permen Jeli Buah Kedondong dengan Penggunaan Jumlah Gula dan Asam Sitrat yang Berbeda. Under Graduates Thesis. Fakultas Teknik - Universitas Malang.

Maryani, Surti, T., \& Ibrahim, R. (2010). Aplikasi gelatin tulang ikan nila merah (Oreochromis niloticus) terhadap mutu permen jeli. Jurnal Saintek Perikanan. 6(1): 62-68.

Miller, J.N. \& Whistler R.L. (1973). Industrial Gum: Polysaccarides and their derivates. $2^{\text {nd }}$ edition, Academic Press. New York.

Mulyasari, Peranginangin, R., \& Sari, A. (2003). Permen Jeli dari Rumput Laut Eucheuma cottonii. Warta Penelitian Perikanan Indonesia. 9(6). 20-26.

Murdinah. (2010). Laporan Program Insentif Peningkatan Kemampuan Peneliti dan Perekayasa. Kementrian Riset dan Teknologi. 20 pp.

Rahmi, N. (1996). Kajian Proses Pembuatan Permen Jelly Jahe. Skripsi. Fakultas Teknologi Pertanian, Institut Pertanian Bogor, Bogor.

Salamah, E., Erungan, A.C. \& Retnowati, Y. (2006). Pemanfaatan Gracilaria sp. dalam pembuatan permen jeli. Jurnal Pengolahan Hasil Perikanan Indonesia. IX(1).

Setyoko, B., Senen, \& Darmanto, S. (2008). Pengeringan Ikan Teri dengan System Vakum dan Paksa. Edisi XI, No 1 Pebruari 2008.

Sholeh R. (2004). Pemanfaatan Madu sebagai Subtitusi Parsial HFS dalam Pembuatan Permen Jeli Madu., Skripsi, Program Studi Teknologi Hasil Ternak., IPB. p. 10-15.

Sinurat, E., Murdinah, \& Bagus, S.B.U. (2006). Sifat fungsional formula kappa dan iota karaginan dengan gum. Jurnal Pascapanen dan Bioteknologi Kelautan dan Perikanan. 1(1): 1-8.

Sudarmadji, S., Haryono, B., \& Suhardi. (1989). Analisis Bahan Makanan dan Hasil Pertanian. Liberty Yogyakarta. $172 \mathrm{pp}$.

Suryaningrum, T.D. (1988). Kajian Sifat-Sifat Mutu Komoditi Rumput Laut Budidaya Jenis Eucheuma cottonii dan Eucheuma spinosum. Tesis. Program Pascasarjana. Fakultas Perikanan dan IImu Kelautan. IPB, Bogor.

Suryaningrum, T.D., Murdinah, \& Arifin, M. (2002). Penggunaan kappa-karaginan sebagai bahan penstabil pada pembuatan fish meat loaf dari ikan tongkol (Euthyinnus pelamys. L). J. Penel. Perik. Indonesia. Edisi Pasca Panen. Badan Riset Kelautan dan Perikanan, Departemen Kelautan dan Perikanan. 8(6): 33-42. 
Tuazon, M. (1996). The use of carragenan and cellulose gel in gummy candy. The Manufacturing Confections 76(11): 62-66.

Utomo, B.S.B., Irianto, H.E., Murdinah, Subaryono, Lestari, D., \& Sinurat, E. (2004). Riset formulasi dan karakterisasi sifat fungsional campuran fikokoloid sebagai penganti gelatin. Laporan teknis Pengembangan Produk Fikokoloid sebagai Subtitusi Pengganti Gelatin. Pengolahan Produk dan Sosial Ekonomi Kelautan dan Perikanan. Jakarta. p. 8-35.
Winarno, F.G., Fardiaz, S., \& Fardiaz, D. (1980). Pengantar Teknologi Pangan. PT. Gramedia Jakarta. p. 5-18.

Winarno, F.G. (1996). Tehnologi Pengolahan Rumput Laut, Pustaka Sinar Harapan, Jakarta.

Winarno, F.G. dan Jennie, B.S.L. (1983). Kerusakan Bahan Pangan. PT. Gramedia. Jakarta.

Yulfa, S.A. (2009). Sifat Organoleptik Permen Jeli Subtitusi Sari Buah Tomat dan Susu. Tugas Akhir (Diploma), Universitas Malang. 


\section{LAMPIRAN 1/APPENDIX 1.}

Parameter dan skor penilaian organoleptik permen jeli/Parameters and organoleptic rating scores for jelly candy assesment.

a. Transparan : (1). Sangat keruh, kotor (2). Keruh, kotor (3). Sedikit keruh kurang bersih, kurang menarik, (4). transparan, bersih, menarik, (5). Sangat transparan, bersih, rapi, menarik./

Transparency: (1). Very turbid, dirty (2). turbid, dirty (3). Slightly turbid less clean, less interesting, (4). Transparent, clean, interesting, (5). Very transparent, clean, nice, interesting

b. Bau :(1). bau tidak enak tercium tajam, (2). bau tidak enak tercium atau ada bau apek, (3). bau netral atau sedikit tidak enak/apek, (4). agak harum sesuai flavor atau bau terlalu kuat, (5). harum, segar sesuai flavor, bau tidak terlalu kuat.I

Odor: (1). sharply smell bad odors, (2). bad odors or no musty smell, (3). neutral or slightly smell bad / musty, (4). A little appropriate flavor or smell fragrant strong, (5). fragrant, fresh flavor appropriate, the smell is not too strong

c. Rasa :(1). tidak enak, rasa lain yang tidak dikehendaki sangat nyata, (2). tidak enak, ada sedikit rasa lain yang tidak dikehendaki, (3). kurang enak, tidak seperti permen jeli, (4). enak, seperti permen jeli, (5). sangat enak, khas permen jeli./

Taste: (1). not tasty, other undesirable taste very real, (2). not tasty, there is little sense of other undesirable, (3). not tasty, not like jelly candy, (4). tasty, like jelly candy, (5). very tasty, typical of jelly candy

d. Tekstur : (1). sangat lengket, berair atau sangat mudah pecah, (2). terlalu lunak, mudah pecah, lengket, (3). tidak lembut, kaku dan mudah pecah, sedikit lengket ketika digigit, (4). kurang lembut, agak kaku, tidak mudah pecah, tidak lengket di mulut waktu digigit, (5). lembut, tekstur pas untuk permen jeli, enak di mulut ketika digigit, dan tidak mudah pecah./

Texture: (1). very sticky, juicy or very easy to break, (2). too soft, easy to break, sticky, (3). not soft, rigid and fragile, a little sticky when bitten, (4). less soft, a little stiff, not easily break, not sticky in the mouth when bitten, (5). soft, fitting texture jelly candy, tasty in the mouth when bitten, and not easily break

e. Elastisitas : (1). sangat tidak elastis, (2). tidak elastis, (3). agak elastis, (4). elastis khas permen jeli, (4). elastis khas permen jeli, (5). sangat elastis khas permen jeli./

Elasticity : very unelastic, (2). Not elastic, (3). Slightly elastic, (4). Typical elastic as jelly candy, (5) very typical of elastic as jelly candy

f. Penerimaan: (1). sangat tidak suka, (2). tidak suka, (3). agak suka, (4). suka, (5). sangat suka./ Acceptance : (1). Very dislike, (2). Dislike, (3), a little like, (4).like, (5), very like 